Prace Filologiczne. Literaturoznawstwo 11(14) 2021

ISSN 2084-6045

e-ISSN 2658-2503

Creative Commons: Uznanie autorstwa 3.0 PL (CC BY)

DOI: $10.32798 /$ pflit.555

\title{
ROK 1989 W LITERATURZE SŁOWACKIEJ - PROBLEMATYCZNA CEZURA
}

\section{The Year 1989 in Slovak Literature - a Problematic Breakthrough Moment}

\author{
RAFAŁ MAJEREK \\ Uniwersytet Jagielloński w Krakowie, Polska \\ E-mail: rafal.majerek@uj.edu.pl \\ https://orcid.org/0000-0003-1333-3763
}

\begin{abstract}
Unarguably the breakthrough nature of the revolutions of 1989 had their impact on the shape of the political system of the former Soviet bloc countries, including Slovakia. From the point of view of literature this breakthrough moment is not that obvious as from the 1990s there have been debates on various detailed aspects and contexts referring to this period of transformation.

The author of this article discusses factors such as pluralism of literary institutions, development of publishing market, the impact of market mechanisms on literary life, and reintegration of literary circulation that establish a condition of Slovak literature the country has never been in before. What changes after 1989 is the perception of the writer's role and thus a new dominant model of an unconstrained writer is being shaped. As to the fields of poetics and text structure, what is most difficult to identify is the unequivocally original solutions as immediately after 1989 no new movement or literary trend comes into being. Yet, the author makes a point that the very fact that the literary texts function in a completely new system of dependencies allows for regarding the year 1989 as a literary breakthrough. This approach, however, implies that the autonomous, formalistic and structuralist model of understanding the history of literature has to be abandoned.
\end{abstract}

Keywords: Velvet Revolution, Slovak literature, literary breakthrough of 1989, pluralism, individualism

\section{Streszczenie}

Przełomowy charakter wydarzeń roku 1989 dla kształtu systemu politycznego w krajach byłego bloku komunistycznego, w tym Słowacji, nie ulega wątpliwości. W dziedzinie literatury cezura ta nie jest tak oczywista, od lat dziewięćdziesiątych XX w. prowadzone są dyskusje poświęcone różnym szczegółowym aspektom i kontekstom okresu transformacji. 
Autor artykułu omawia zjawiska, które potwierdzają nową sytuację literatury słowackiej: pluralizm instytucji literackich, rozwój rynku wydawniczego, wpływ mechanizmów rynkowych na życie literackie, reintegrację obiegów literackich. Po 1989 r. zmieniają się także wyobrażenia o roli pisarza, dominujący staje się model indywidualistyczny. W dziedzinie poetyki i struktury tekstów najtrudniej wskazać zdecydowanie nowe rozwiązania, bezpośrednio po 1989 r. nie pojawił się nowy prąd czy tendencja literacka. Autor podkreśla jednak, że sam fakt usytuowania i funkcjonowania tekstów literackich w zupełnie nowym systemie relacji pozwala na potraktowanie 1989 r. w kategoriach przełomu literackiego. Podejście takie wiąże się z rezygnacją z autonomicznego, formalistyczno-strukturalistycznego modelu rozumienia historii literatury.

Słowa kluczowe: aksamitna rewolucja, literatura słowacka, przełom literacki 1989, pluralizm, indywidualizm

Zagadnienie cezury roku 1989 od lat dziewięćdziesiątych XX w. stanowi jeden z ważnych tematów słowackich prac historyczno- i krytycznoliterackich. Podejmowane było w powstających w pierwszej dekadzie transformacji próbach wyznaczenia i opisu aktualnych tendencji rozwojowych poezji i prozy, w prowadzonych na łamach czasopism dyskusjach na temat najnowszych zjawisk, rozważano je także w kontekście formułowanych postulatów i oczekiwań, dotyczących roli społecznej pisarzy w nowej sytuacji społeczno-politycznej i kulturowej. Dominującym tonem w pracach tego okresu był ton rozczarowania, zniecierpliwienia i pretensji. Pożądana była zmiana, najlepiej związana z nową generacją i znaczące zdynamizowanie procesu literackiego, określona reakcja i odpowiedź na uzyskaną wolność. Tymczasem, zwłaszcza w pierwszej połowie lat dziewięćdziesiątych, pojawiało się wrażenie „bezruchu, wyczerpania, sterylności, rezygnacji”" Frustrację, którą część środowiska otwarcie wyrażała, uznać można za zrozumiałą, wydarzenia roku 1989 mogły bowiem uzasadniać wspomniane projekcje i nadzieje, wynikające, dodajmy, $z$ pewnych, utrwalonych w poprzednim systemie sposobów myślenia o przełomach ${ }^{2}$. $Z$ upływem czasu rozważania o cezurze 1989 stały się częścią opracowań o charakterze syntetycznym i tekstów poświęconych możliwym konceptualizacjom historii literatury współczesnej. Jednym z podstawowych problemów było, zarówno w pracach pisanych z perspektywy lat dziewięćdziesiątych, jak i późniejszej, określenie relacji między przełomem politycznym a nowym kształtem literatury i życia literackiego.

${ }^{1}$ P. Matejovič, Literatúra, „život” a vy... (Anketa), „Rak” 1999, nr 6, s. 47. Fragmenty tekstów słowackich, jeśli nie podano inaczej, w tłumaczeniu autora artykułu.

${ }^{2}$ Sytuacja słowacka pod tym względem jest podobna do polskiej, o której Julian Kornhauser pisze: „Bezpośrednio po 1989 roku powszechne stało się oczekiwanie na przełom w literaturze. Choć było to zrozumiałe, $\mathrm{z}$ historycznego punktu widzenia nie miało żadnego uzasadnienia. Czekanie na przełom było typowym myśleniem minionej epoki”. J. Kornhauser, Międzyepoka. Szkice o poezji i krytyce, Kraków 1995, s. 18. 
W porządku politycznym kluczowe były wydarzenia aksamitnej rewolucji, której symbolem stała się zorganizowana 17 listopada przez środowiska studenckie manifestacja w Pradze, brutalnie rozpędzona przez tzw. siły porządkowe ${ }^{3}$. Kolejne protesty w miastach czeskich i słowackich oraz dynamiczne działania ruchów opozycyjnych, mimo podejmowanych przez komunistów prób utrzymania władzy, doprowadziły do upadku systemu i rozpoczęcia przemian ustrojowych. Z perspektywy literaturoznawczej natomiast sygnały nadchodzących przemian można wskazać wcześniej. Mam na myśli zarówno inicjatywy młodych twórców podejmowane w drugiej połowie lat osiemdziesiątych (m.in. powstałe w 1985 r. Koło Młodych Autorów, samizdatowe czasopismo „Fragment K”), jak i odważne głosy badaczy, którzy wskazywali konieczność zmiany sposobów myślenia o literaturze, krytycznie oceniali jego ideologiczne uwikłania oraz, odwołując się do wartości estetycznych i etycznych, oficjalnie formułowali pewne propozycje i postulaty.

Znaczącą rolę odegrały zwłaszcza, opublikowane kolejno w pierwszych dwóch numerach z 1989 r. pisma „Slovenské pohl'ady”, artykuły Milana Šútovca „Początek lat siedemdziesiątych jako problem historycznoliteracki” (Začiatok sedemdesiatych rokov ako literárnohistorický problém $)^{4}$ oraz Evy Jenčíkovej i Petra Zajaca „Sytuacja współczesnej literatury słowackiej” (Situácia súčasnej slovenskej literatúry $)^{5}$. Żywo dyskutowane, stały się inspiracją do zorganizowania w Budmericach „okrągłego stołu”, spotkania, które było „po długim okresie wymuszonej intelektualnej kwarantanny jednym z impulsów ożywienia zablokowanego przez całe dekady życia literackiego"7.

W wystąpieniach otwarcie krytykowano aktualną politykę kulturalną, domagano się powrotu autorów zakazanych, co więcej, jeden z nich, Milan Hamada wziął udział w obradach ${ }^{8}$. Wyzwanie, jakie stanęło przed literaturą, Š́tovec opisywał w artykule dotyczącym przebiegu budmerickiej konferencji następująco:

Fundamenty aktualnych kryteriów aksjologicznych i norm estetycznych, podobnie jak organizacyjnych i innych struktur życia literackiego, powstały w pierwszej ćwierci lat 70. jako produkty przekonań i praktyk bezpośrednio lub pośrednio wyprowadzanych z wymogu jednoznacznego

${ }^{3}$ Należy dodać, że dzień wcześniej, 16 listopada, na Uniwersytecie Komenskiego w Bratysławie rozpoczął się nielegalny strajk studencki, określany jako prolog do aksamitnej rewolucji. Vide Kolektív autorov, Studentský prológ k Nežnej revolúcii, Bratislava 2019.

${ }^{4} \mathrm{M}$. Šútovec, Začiatok sedemdesiatych rokov ako literárnohistorický problém, „Slovenské pohl'ady" 1989 , nr 1, s. 29-43.

${ }^{5}$ E. Jenčíková, P. Zajac, Situácia súčasnej slovenskej literatúry, „Slovenské pohl’ady” 1989, nr 2, s. 45-71.

${ }^{6}$ M. Šútovec, Literatúra v diskusii, w: idem, Zo šedej zóny, Bratislava 1999, s. 155.

${ }^{7}$ P. Matejovič, Viac odvahy k premýšl'aniu, „Rak” 1996, nr 6, s. 17.

${ }^{8}$ S̆. Drug, Z literárnych sporov po novembri 1989, w: idem, Literatúra a politika po slovensky, Bratislava 2003, s. 215. 
politycznego zaangażowania literatury. [...] jeśli jednak literatura ma uzyskać nową dynamikę i jeśli ma w nowym dynamicznym ruchu urzeczywistnić zwrot w stronę człowieka, jego potrzeb, nadziei, konfliktów, pełni jego życia uczuciowego i intelektualnego, konieczne jest rozbicie ograniczającej obręczy tak zwanych zobowiązań społecznych sztuki słowa: ona ma przecież zobowiązania przede wszystkim wobec człowieka ${ }^{9}$.

Świadomość bliskości punktu zwrotnego, chęć odcięcia się od wyznaczanych przez praktyki normalizacyjne modeli i wskazanie potrzeby ,radykalnej przebudowy systemu, której ważnym komponentem ma być otwarta, demokratyczna dyskusja" 10 - te wątki powracać będą w pracach literaturoznawczych powstających tuż przed i po wydarzeniach z listopada 1989 r. Charakterystyczne w nich jest również przekonanie, że warunki wolności twórczej niejako automatycznie doprowadzą do znaczącego zdynamizowania, rozumianego w kategoriach teleologicznych, rozwoju literatury. Nadzieje te, jak wspomniałem na początku, okazały się płonne, pierwsze lata transformacji nie przyniosły ani zdecydowanie nowych elementów w sferze tematycznej, ani istotnych przemian na płaszczyźnie poetyki i struktury tekstów ${ }^{11}$. Wyznaczanie cezury w literaturze słowackiej w roku aksamitnej rewolucji, niewątpliwie kuszące i nawiązujące do tradycyjnych, choć krytykowanych w przypadku słowackim co najmniej od prac strukturalistycznych Mikuláša Bakoša ${ }^{12}$, praktyk tworzenia podziałów periodyzacyjnych na podstawie wydarzeń pozaliterackich, jest więc w pewien sposób problematyczne. Rok 1989 będzie jednak zwykle eksponowany w artykułach, monografiach i syntezach historycznoliterackich, w ich tytułach lub sposobie porządkowania problematyki. Można odnieść w związku z tym wrażenie pewnej niekonsekwencji czy ambiwalencji. Odczucia takiego można uniknąć lub je znacząco złagodzić, gdy przełom rozpatrywać będziemy z uwzględnieniem jego różnych kontekstów i relacji między tymi kontekstami.

W opisie sytuacji literatury słowackiej omawianego okresu warto wykorzystać, jako ogólną ramę, formułowane w odniesieniu do literatury polskiej propozycje Przemysława Czaplińskiego. W pierwszych zdaniach monografii Ślady przetomu czytamy:

Jesteśmy świadkami i uczestnikami przełomu literackiego. Przełom nie jest jednak zjawiskiem jednorodnym [podkr. - P.C.]. Gdy nadchodzi, rozgrywa się przynajmniej w trzech sferach: poetyk, idei i instytucji. W pierwszej z nich przełom dokonuje się wtedy, gdy kryzys przeżywają jedne gatunki i konwencje, a funkcję nośnika treści istotnych przejmują inne,

\footnotetext{
${ }^{9}$ M. Š́tovec, op. cit., s. 156.

${ }^{10}$ Ibidem, s. 158.

${ }^{11}$ V. Mikula, Novodobá slovenská literatúra, w: idem, Čakanie na dejiny. State k slovenskej literárnej histórii, Bratislava 2013, s. 35.

${ }^{12}$ M. Bakoš, Problém vývinovej periodizácie slovenskej literatúry, Trnava 1944.
} 
gdy wyczerpują się formy dotąd akceptowane, a w ich miejsce pojawiają się nowe, wyraźnie odmienne od dotychczasowych, ucieleśnione w wybitnych dziełach. Sferę drugą, obszar idei, przełom zagarnia wtedy, gdy nowy mit sztuki usuwa idee dotychczasowe, gdy zmieniają się sposoby patrzenia na literaturę i sposoby użytkowania literatury, style spierania się o nią i postawy wobec niej. I wreszcie w sferze trzeciej, instytucjonalnej, przełom rozgrywa się wtedy, gdy zmieniają się zasady produkcji i rozpowszechniania literatury, relacje między pisarzem i mecenasem, między urzędem i wydawcą, szkołą i rynkiem, gdy pojawiają się nowe techniki promocji i prawidła debiutu, kryteria sukcesu i obiegi czytelnicze ${ }^{13}$.

Biorąc pod uwagę specyfikę wymienionych sfer, oczywiste jest, że nowe zjawiska mogą się w nich pojawiać w różnym tempie i z różną intensywnością. Krytyczne i kwestionujące przełom głosy badaczy słowackich dotyczyły płaszczyzny estetyki i odwoływały się przede wszystkim do tych modeli rozumienia procesu literackiego, które eksponują autonomię literatury, a zmiany pozwalające mówić o nowym etapie rozwojowym utożsamiają z istotnym przekształceniem struktury literackiej. W odniesieniu do dwóch pozostałych sfer cezurę roku 1989 trudno jest podważyć, gdyż zarówno ideowe postawy wobec literatury, jak i jej instytucjonalne funkcjonowanie uległy daleko idącym przekształceniom. Przełom najwyraźniej manifestował się w sposobach organizacji życia literackiego, funkcjonowaniu rynku wydawniczego, dostrzegalny był również w sposobach rozumienia funkcji literatury i jej związków z innymi dziedzinami życia społecznego.

Zmierzch centralnego zarządzania kulturą umożliwił powstanie zróżnicowanych ideowo i literacko organizacji pisarzy. Na fali sporów dotyczących koncepcji działania, zadań, struktury organizacyjnej, począwszy od nadzwyczajnego zjazdu Związku Pisarzy Słowackich w grudniu 1989 r., powstawały kolejno: Gmina Pisarzy Słowacji, Stowarzyszenie Pisarzy Słowackich, Klub Niezależnych Pisarzy oraz organizacje reprezentujące twórców węgierskich i ukraińskich; z powodów administracyjnych powołano także parasolową instytucję - Zrzeszenie Organizacji Pisarzy na Słowacji. Sytuację dyskusji i konfrontacji stanowisk uznać by można za produktywną i potwierdzającą zdecydowanie nową jakość życia literackiego, w przypadku słowackim doszło jednak do prób ideologicznego podporządkowania sfery kultury i literatury władzy państwowej, wyraźnie powtarzających schematy z okresu komunizmu. Działania rządu Vladimíra Mečiara w latach 1992-1998, pod hasłem obrony „narodowych priorytetów”, zmierzały do odnowienia centralizmu i ożywienia kultury monologu. Ograniczenie wolności słowa było w nowym ustroju, oczywiście, niemożliwe, więc zakładane cele rząd chciał osiągnąć narzędziami cenzury ekonomicznej. Próby wywierania przez polityków wpływu na kształt życia literackiego doprowadziły do wyraźnej polaryzacji

\footnotetext{
${ }^{13}$ P. Czapliński, Ślady przełomu. O polskiej prozie 1976-1996, Kraków 1997, s. 5.
} 
środowiska twórczego, widocznej nie tylko w sferze instytucji, ale także na rynku wydawnictw książkowych i czasopiśmienniczych. Odwołując się do teorii Pierre'a Bourdieu, można ją opisać jako konflikt biegunów heteronomicznego i autonomicznego w obrębie pola literackiego, podział między tą częścią produkcji literackiej, która jest zależna od sił zewnętrznych, konkretnie dyktatu politycznego, oraz tą, która reprezentuje zasady wolności artystycznej ${ }^{14}$. Szczegółowo problematyki ideologicznego rozłamu w życiu literackim nie będę omawiał ${ }^{15}$, dla prezentowanych rozważań najistotniejsze jest, że działania zmierzające do kontroli literatury, choć miały szereg negatywnych efektów, nie zakończyły się sukcesem. Warunki pluralizmu, stworzone dzięki zmianie systemowej, udało się utrzymać nawet w okresie mecziaryzmu, co widoczne było w zróżnicowanej ofercie wydawniczej, powstających pismach, aktywności instytucji promujących literaturę.

Zależność produkcji literackiej od mechanizmów rynkowych, zorientowanie jej na zysk ekonomiczny to kolejny nowy element sytuacji po 1989 r. Nurt literatury komercyjnej, również sytuujący się na heteronomicznym biegunie pola literackiego, szybko stał się fenomenem tak silnie oddziałującym na kształt rynku książki, że niektórzy krytycy zaczęli w czarnych scenariuszach przewidywać zanik literatury „ambitnej” czy wręcz koniec kultury słowackiej ${ }^{16}$. Wyspecjalizowana gatunkowo, odpowiadająca na konkretne zapotrzebowanie czytelnicze produkcja (słowackie steelovky, czyli rodzime odpowiedniki romansów amerykańskiej pisarki Danielle Steel, kryminały, thrillery, utwory z kręgu fantasy itd.) była promowana za pomocą nowoczesnych technik marketingowych, w przemyślany sposób dystrybuowana i rzeczywiście, biorąc pod uwagę sprzedawane nakłady, zyskała niezwykłą popularność. Istotne jest, że również biegun autonomiczny poddawany był naciskom rynkowym. W jego przypadku jednak chodziło głównie o przetrwanie małych, niezależnych wydawców, a nie o gromadzenie kapitału ekonomicznego. Utrzymanie się na rynku wymagało oswojenia się $\mathrm{z}$ jego warunkami i przyjęcia określonych strategii promocji, budowania marki itd., choć główną stawką dla twórców tego nurtu pozostawał kapitał symboliczny. Sygnalizuję tutaj jedynie kwestie, które wymagałyby dokładniejszych badań; hasłowe przywołanie terminów z zakresu socjologii literatury jest celowe,

${ }^{14}$ J. Šrank, Situácia slovenskej literatúry na konci 20. a začiatku 21. storočia (K pluralizmu literárneho pol'a), w: Tradycja $i$ wyzwania. Metodologia badań slawistycznych XX i XXI wieku, red. H. Mieczkowska, E. Solak, P. Fałowski, N. Palich, Kraków 2015, s. 372.

${ }^{15}$ Dokładniejsze informacje na ten temat znaleźć można m.in. w artykułach: S. Chrobáková, Literatúra v diskusii I, „Slovenská literatúra” 1999, nr 1, s. 1-14; R. Majerek, Przestrzenie pamięci - rewitalizacje mitu i próby reinterpretacji tradycji $w$ dyskursie stowackim po 1989 roku, w: Kultury stowiańskie między postkomunizmem a postmodernizmem, red. M. Dąbrowska-Partyka, Kraków 2009, s. 45-62.

${ }^{16}$ D. Kršáková, Situácia súcasnej slovenskej literatúry 1, http://www.iliteratura.cz/Clanek/17307/ situacia-sucasnej-slovenskej-literatury-1- (d.d. 15.03.2020). 
jej koncepcje pozwoliłyby, w moim przekonaniu, uporządkować i opisać szereg problemów okresu przełomu ${ }^{17}$.

Kolejny wynikający ze zmiany systemu politycznego fakt, mianowicie zniesienie cenzury, rozpoczyna proces integracji obiegów literackich. Stopniowo czytelnikom udostępniano teksty, które wcześniej były zakazane i ukazywały się w wydawnictwach samizdatowych lub zagranicznych. Do życia literackiego powracają autorzy emigracyjni, niektórzy pisarze publikują utwory starsze, których w okresie komunizmu świadomie nie proponowali wydawnictwom, przewidując brak zgody na wydanie lub znaczące ingerencje w tekst. Początek tych działan, określanych jako wypełnianie „białych plam” w literaturze słowackiej ${ }^{18}$, oceniany bywał jako chaotyczny i fragmentaryczny, m.in. ze względu na znacznie opóźnione udostępnienie utworów najważniejszego słowackiego dysydenta z kręgów literackich, Dominika Tatarki, czy w niektórych wypadkach bezkrytyczne budowanie pozytywnej oceny tekstów jedynie na podstawie faktu ich funkcjonowania poza oficjalnym nurtem przed 1989 r. ${ }^{19}$ Proces integracyjny z czasem jednak przyniósł interesujące efekty, dając możliwości bardziej wszechstronnego i kompleksowego spojrzenia na dorobek drugiej połowy XX w.

Problemy związane ze sposobem rozumienia roli pisarza w nowej rzeczywistości, głośno wyrażane poczucie utraty społecznego autorytetu i prestiżu, reakcje niepewności i frustracji ukazują jeszcze jeden wymiar dokonującej się na początku transformacji zmiany. Sytuację kryzysu wyobrażeń o miejscu twórcy lapidarnie komentował Pavel Michalovič: „Pisarz, dzięki Bogu, przestał być sumieniem narodu, ale dzisiaj jakby zupełnie nie wiedział, kim/czym chciałby być" ${ }^{20}$. Podobne wątpliwości wyrażali inni krytycy i twórcy, chociażby Martin Kasarda: „Wolność mediów pozbawiła literaturę piękną konieczności spowijania w obłoki metafor stwierdzenia, że nie da się tutaj żyć [...]. O czym jednak teraz pisać,

${ }^{17}$ Pewne propozycje w tym zakresie sformułował Jaroslav Šrank w przywoływanym wcześniej artykule Situácia slovenskej literatúry, s. 369-376. Przydatność podejścia socjologicznego w badaniach przemian literatury w krajach postkomunistycznych po 1989 r. potwierdzają efekty projektu Literatura polska po 1989 roku w świetle teorii Pierre’a Bourdieu, zwłaszcza dwa $\mathrm{z}$ trzech opublikowanych w jego ramach tomów: G. Jankowicz, P. Marecki, A. Palęcka, J. Sowa, T. Warczok, Literatura polska po 1989 roku w świetle teorii Pierre'a Bourdieu. Raport z badań, Kraków 2014; Literatura polska po 1989 roku w świetle teorii Pierre'a Bourdieu. Podręcznik, red. G. Jankowicz, P. Marecki, M. Sowiński, Kraków 2015. 1991.

${ }^{18}$ J. Hvišč, V. Marčok, M. Bátorová, V. Petrík, Biele miesta v slovenskej literatúre, Bratislava

${ }^{19}$ Jak zauważa Štefan Drug: „Dla jednych wzorem stali się Tatarka i Mňačko, inni odkrywali katolicką modernę, po latach wyolbrzymiali znaczenie i wartość dzieł jej przedstawicieli, przy tym niektórzy w jej obrębie ahistorycznie umieszczali wszystkich autorów wyznania katolickiego. Emigracja niemal stała się znakiem jakości. Bez wątpienia chodziło o nieuniknioną chorobę okresu przejściowego, bowiem aktywności tego typu szybko zaprzestano i zaczęto proponować realniejsze spojrzenie na wartości i problemy”. Š. Drug, op. cit., s. 219.

${ }^{20}$ P. Michalovič, Malá úvaha o literatúre, o dobe a všeličom inom, „Romboid” 2000, nr 6, s. 4. 
pisarze?"21. Zaangażowanie polityczne w latach rządów Mečiara, wynikające u niektórych z prostej kalkulacji i chęci przypodobania się władzy, u innych motywowane sprzeciwem wobec praktyk rządzących i obowiązkiem obrony wartości demokratycznych, było powtarzaniem schematów z poprzedniego ustroju, tylko tym razem w oficjalnym obiegu. Konkurencyjne propozycje się nie pojawiały, pomysły na inne niż polityczne uczestnictwo w życiu wspólnoty czy nowy mit pisarza nie zostały sformułowane. Popularne natomiast stały się gesty wycofania się i zgoda na pozycję literatury na peryferiach życia społecznego, jak dramatycznie ujmował to Kasarda: „już tylko we własnym lochu, czekając na ostatnie tchnienie"22. Sytuacji tej sprzyjała dominująca wśród pisarzy niechęć do wpisywania własnej twórczości w ramy jakiejkolwiek działalności kolektywnej, na przykład grupy literackiej, i podkreślany kult indywidualizmu. Pojawiły się próby wypełnienia ideologicznej próżni elementami filozofii i teorii ponowoczesnych ${ }^{23}$, które, w połączeniu z postmodernistycznymi strategiami tekstowymi, pogłębiały dystans między twórcą i rzeczywistością; dotyczyło to, jak zauważa Ivana Taranenková, zwłaszcza debiutantów:

W przypadku autorów, którzy pojawili się w literaturze słowackiej na początku lat 90., rzuca się w oczy przede wszystkim ich osobność, preferowana ekskluzja, wręcz autyzm (charakterystyczne, że dominującym „bohaterem naszych czasów” na następne lata stał się outsider, a dominującym tematem samotność), deklarowana niechęć do jakichkolwiek znaków autentyczności w literaturze, podkreślanie zasady gry i sztuczności tekstu literackiego. Zamiast pozorów realnego świata w tekstach z lat 90 . dominują mistyfikacja, ironia, parodia oraz eksperyment ${ }^{24}$.

Eksponowanie wybranych elementów kojarzonych z poetyką postmodernizmu wpływało również na relacje tekst-odbiorca, co podkreśla z kolei Marta Součková:

Odbiorcy współczesnej słowackiej literatury często nie zostaje nic innego, jak udawać, że bawi się przypadkowymi konfiguracjami [podkr. - M.S.] [...], że z chęcią błądzi w tekstowych labiryntach, że jest kolekcjonerem książkowych produktów i widzem [podkr. - M.S.] [...] tekstowych gier. Jeśli człowiek w przeszłości komunikował się, to po to, aby potwierdzić własną egzystencję, dzisiejszy, współcześnie piszący twórca znika, rozpływa się w tekście ${ }^{25}$.

${ }^{21}$ M. Kasarda, Literatúra si našla svoje miesto, stačí napísat’ nekrológ, „Romboid” 2000, nr 6, s. 8 .

${ }^{22}$ Ibidem, s. 10.

${ }^{23}$ T. Beasley-Murray, Súčasná slovenská literatúra, diabolská zmluva s teóriou a genitalisti, „Rak” 2000, nr 3, s. 11.

${ }^{24}$ I. Taranenková, Premeny poetík? (Niekol'ko poznámok $k$ reflexii slovenskej literatúry po roku 1989), „Slovenská literatúra” 2009, nr 6, s. 76.

${ }^{25}$ M. Součková, Różne formy podmiotu w literaturze stowackiej po 1989 roku, thum. M. Buczek, w: Literatury stowiańskie po roku 1989. Nowe zjawiska, tendencje, perspektywy, t. 3: Podmiotowość, red. B. Czapik-Lityńska, Warszawa 2005, s. 92. Wyróżnione przez autorkę zwroty to nawiązanie do tytułów dwóch książek prozaika Tomáša Horvátha - „Kilka przypadkowych konfiguracji” (Niekol'ko náhlych konfigurácií, 1997) i „Widz” (Divák, 2002); w cytacie pomijam zamieszczone w nawiasach dane bibliograficzne. 
Nowe zjawiska w zakresie postaw twórców i rozumienia relacji literatury z kontekstem społecznym będą pojawiały się stopniowo, zwłaszcza w drugiej połowie lat dziewięćdziesiątych; ze znaczących przykładów wymienić można nurt feministyczny, związany z pismem i wydawnictwem „Aspekt”, czy strategie budowania marki pisarza realizowane przez Michala Hvoreckiego.

Wyraźne wskazanie znaków przełomu na płaszczyźnie poetyki, zwłaszcza na początku okresu transformacji, jest znacznie trudniejsze niż ich identyfikacja w wyżej przedstawionych sferach. Badacze w tym zakresie wydają się zgodni, podkreślają raczej pewne kontinuum rozwojowe, odrzucając tym samym zasadność mówienia o przełomie ${ }^{26}$. Niewątpliwie rok 1989 oznaczał definitywne odrzucenie metod realizmu socjalistycznego, pamiętać jednak należy, że kwestionowanie jego zasad wyraźnie dostrzegalne było w latach osiemdziesiątych. Zgodnie z propozycją Jenčíkovej i Zajaca kluczową rolę w tym procesie odegrała powieść „Rozum” (Rozum, 1982) Rudolfa Slobody, w której „prawdopodobnie po raz pierwszy przedstawiony został [...] brak autentyzmu życia ostatnich dekad, prowadzący do brutalizacji życia i upadku elementarnych zasad humanizmu w zasadniczych relacjach społecznych" ${ }^{27}$. Istotne w tym kontekście były również teksty na przykład Dušana Mitany, Jána Johanidesa oraz publikowane w czasopismach $w$ drugiej połowie lat osiemdziesiątych debiutanckie utwory, między innymi Petra Pišt'anka. Za najważniejsze jednak uznawano relacje literatury lat dziewięćdziesiątych z procesami, które przebiegały w latach sześćdziesiątych, i właśnie w tym okresie sytuowano cezurę współczesnej literatury słowackiej. Zgodnie z propozycją Zajaca:

Pomiędzy latami sześćdziesiątymi a dziewięćdziesiątymi istnieje ścisły związek. Pod względem politycznym wcześniejszy okres był tylko próbą wewnętrznej przemiany systemu, ale pod względem literackim stanowił przełom i periodyzacyjny punkt graniczny okresu, który wciąż jeszcze trwa [podkr. - R.M.]. Lata dziewięćdziesiąte były natomiast przełomem politycznym, ale już nie literackim ${ }^{28}$.

Autor, odwołując się do wprowadzonych do wiedzy o literaturze przez Oskára Čepana pojęć zaczerpniętych z geologii, pisze o trzech rodzajach ruchów charakteryzujących proces literacki: tektonicznych, przemieszczających i przełomowych, a następnie stwierdza, że w literaturze po 1989 r. mamy do czynienia z przemieszczaniem całych kompleksów warstw, które ma dwa aspekty: z jednej strony

${ }^{26}$ Vide m.in. V. Mikula, Novodobá slovenská literatúra; M. Součková, P[r]ózy po roku 1989, Bratislava 2009, s. 17-21; I. Hochel, Vývinové kontexty a súvislosti, w: I. Hochel, L. Čúzy, Z. Kákošová, Slovenská literatúra po roku 1989, Bratislava 2007, s. 12; D. Kršáková, op. cit.

${ }^{27}$ E. Jenčíková, P. Zajac, op. cit., s. 18.

${ }^{28}$ P. Zajac, Literatura słowacka na końcu $X X$ wieku, tłum. A. S. Jagodziński, „Literatura na Świecie" 2007, nr 7-8, s. 362. 
podtrzymuje ciągłość, $\mathrm{z}$ drugiej z nią zrywa ${ }^{29}$. Istotne w rozważaniach Zajaca jest stwierdzenie, że przemiany w latach dziewięćdziesiątych nie mają charakteru przełomowego, związanego z wymianą struktur, czy „kompleksów warstw”. Zgodzić się można, że w pierwszych latach transformacji tak zwana starsza średnia generacja, której debiuty przypadają właśnie na lata sześćdziesiąte (m.in. Pavel Vilikovský, Dušan Mitana, Ján Johanides, Rudolf Sloboda) w decydujący sposób wpływała na kształt literatury. Zauważyć jednak należy, że w twórczości debiutantów lat dziewięćdziesiątych dostrzec można pewne zmiany, choć często ograniczać się one będą do radykalizacji niektórych wcześniejszych strategii.

Rozbicie tradycyjnej struktury tekstu, fragmentaryczność, synkretyzm, ostentacyjna intertekstualność, antyreferencjalność, autotematyzm, wykorzystywanie konwencji literatury popularnej, ironii, parodii i pastiszu, strategia niezobowiązującej gry z czytelnikiem, czyli zjawiska, które możemy utożsamiać z literaturą postmodernistyczną, w pewnym zakresie obecne były od lat sześćdziesiątych. W utworach przedstawicieli młodego pokolenia zajęły jednak miejsce kluczowe, w pewien sposób zmieniając, moim zdaniem, kształt literatury. Z wymienionych strategii inaczej korzystali, ograniczając się zaledwie do kilku przykładów, Peter Pišt'anek, Balla, Tomáš Horváth, Peter Macsovszky, Peter Šulej, niemniej dla wszystkich stanowiły one podstawowy punkt odniesienia. W sferze tematycznej także można mówić o tendencji do radykalizacji sposobów podejmowania niektórych problemów, polegającej głównie na detabuizacji zagadnień dotyczących seksualności, przemocy, zła ${ }^{30}$. Nową jakość literatury debiutantów, nawet jeśli nie polegała ona na zdecydowanym przebudowaniu struktury literackiej, potwierdzać mogą niektóre głosy krytyki i nie mam tutaj na myśli negatywnych ocen, ale ich sankcjonowanie określonym wyobrażeniem o granicach literatury, przekonaniem o stabilnym pojęciu literackości, które w konfrontacji z nowymi tekstami ukazywało swój anachronizm ${ }^{31}$. Opis zjawisk z zakresu prozy, określanych mianem ,poetyki coolness" ${ }^{\prime 2}$, czy w poezji propozycji tzw. generacji tekst $^{33}$ wymagał przemyślenia perspektywy badawczej i stosowanego aparatu krytycznego. Wspominam jedynie wybrane tendencje, produkcja literacka lat dziewięćdziesiątych, choć wielu rozczarowywała, była zróżnicowana pod względem realizowanych poetyk i tematyzowanych zagadnień; pluralizm postaw twórczych,

${ }^{29}$ Ibidem, s. 363.

${ }^{30}$ M. Součková, P[r]ózy po roku 1989, s. 27.

${ }^{31}$ Najciekawszym przykładem tego typu reakcji i pytań o granice literatury jest recepcja powieści Petra Pišt’anka Rivers of Babylon (1991), dzisiaj uznawanej za jeden z najważniejszych tekstów lat dziewięćdziesiątych. Vide V. Barborík, Slovenská kritika pláva vo vodách Babylonu, w: Fórum mladej literárnej kritiky, red. A. Bžoch, M. Kasarda, Bratislava 1992, s. 22-29.

${ }^{32}$ U. Rassloff, Poetika coolness? Mladá slovenská próza po roku 1989, „Rak” 1999, nr 5, s. $24-32$.

${ }^{33}$ J. Šrank, Poème fatal (Text generation. Zvodcovia zmyslu), „Romboid” 2000, nr 6, s. 19-30. 
potwierdzający proces poszukiwania nowych środków ekspresji, stał się najwyraźniejszym znakiem sytuacji po $1989 \mathrm{r}$.

Pojęcie pluralizmu, pojawiające się w wielu pracach, nie było powszechnie akceptowane jako kategoria opisowa. Zdecydowanej krytyce poddane zostało przez Valéra Mikulę w komentarzu do fragmentów syntezy historii literatury słowackiej drugiej połowy XX w., przygotowanej pod kierunkiem Viliama Marčoka $^{34}$. Mikula zwraca uwagę na socjologiczno-polityczny charakter terminu pluralizm, odrzuca „ramy periodyzacyjne wyprowadzane z polityki, a nie literatury" 35 , postuluje periodyzację opartą na kryteriach estetycznych. Podkreśla, odwołując się także do innych prac, że w odniesieniu do starszych epok zasady te zwykle bywają respektowane, natomiast w ujęciach historii literatury XX w. ich brakuje ${ }^{36}$. Wyznaczanie cezury w 1989 r. uznaje za niesłuszne. Podobnie jak Zajac, zwraca uwage na przełom we wcześniejszym okresie i proponuje: „Abyśmy lepiej zrozumieli wszystkie przemiany literatury słowackiej ostatnich sześciu dekad, być może należałoby spróbować potraktować jej cztery komunistyczne dziesięciolecia razem z dwoma postkomunistycznymi jako jedną całość [podkr. - V.M.]"37.

Jak widać z przytoczonych opinii, kwestionowanie przełomu literackiego w 1989 r. w słowackich pracach literaturoznawczych odbywa się w horyzoncie tradycji formalistyczno-strukturalistycznej i jest w jej ramach uzasadnione. Problemem takiego podejścia jest to, że o ile sprawdzało się ono w modelowaniu procesu literackiego starszych epok (nieprzypadkowo Mikula podkreśla respektowanie kryteriów estetycznych w opisach rozwoju literatury do początku XX w.), o tyle jest trudne do konsekwentnej aplikacji do materiału literatury nowszej, w której brak jednej dominującej tendencji. W literaturze po 1989 r. obecne są rozmaite poetyki, rozwiązania formalne i propozycje tematyczne, jest ona zdecentralizowaną przestrzenią, a kategoria pluralizmu, choć nie jest kategorią stricte literaturoznawczą, wskazuje jej specyfikę. Dodać warto, że autonomiczny model rozumienia i uprawiania badań historycznoliterackich został we współczesnych teoriach zakwestionowany. Postuluje się odejście od prób tłumaczenia skomplikowanych sieci zjawisk ukrytym porządkiem strukturalnym na rzecz uwzględniania w pracach literaturoznawczych wielowymiarowych uwarunkowań kontekstowych ${ }^{38}$.

${ }^{34}$ V. Marčok a kolektív, Dejiny slovenskej literatúry III. Cesty slovenskej literatúry druhou polovicou XX. storočia, Bratislava 2004.

${ }^{35}$ V. Mikula, Hodnoty a literárne dejiny. K situácii slovenskej literárnej historiografie, w: idem, Čakanie na dejiny, s. 156.

${ }^{36}$ Idem, Estetikum či politikum? Medzníky v slovenskej literatúre po roku 1945, w: idem, Čakanie na dejiny, s. 164.

${ }^{37}$ Ibidem, s. 167.

${ }^{38}$ R. Nycz, Możliwa historia literatury, w: idem, Poetyka doświadczenia. Teoria - nowoczesność - literatura, Warszawa 2012, s. 163. 
Można założyć, że w ramach opisu najnowszej literatury słowackiej, który bierze pod uwagę jej skomplikowane relacje z różnymi kontekstami: politycznym, ideologicznym, ekonomicznym, kulturowym, cywilizacyjnym, dostrzegalne będą zmiany, jakie w okresie transformacji przechodziła, oraz różnice w porównaniu z jej kształtem przed aksamitną rewolucją. W ramach takiej konceptualizacji zasadne, moim zdaniem, będzie wyznaczenie cezury w 1989 r. Jak bowiem trafnie zauważa Czapliński:

[...] zmiana ustrojowa, choć nie musi wywoływać zmiany poetyk, powoduje zmianę położenia i postrzegania literatury, zmianę jej usytuowania wobec rynku, polityki, pieniądza, źródeł społecznych wzorców osobowościowych, potrzeb i zamówień odbiorcy. W takiej sytuacji sztuka choćby nie miała do zaproponowania niczego nowego - ulega zmianom, ponieważ znaczy co innego, jest inna, ponieważ znajduje się w nowym układzie. Przełom w literaturze nie musi być więc realny, ponieważ jest aż nadto realny wokół niej - w oczekiwaniach deklaracji światopoglądowych, nowych gustach i nowych kryteriach oceny, nowych kategoriach, które się do niej przykłada, nowych językach opisu, nowych sporach o jej obowiązki ${ }^{39}$.

Przełom polityczny stworzył niezbędne warunki do wymienionych w cytowanym fragmencie zmian, a także umożliwił budowanie nowych form zaangażowania literatury, przejawiającego się w podważaniu dominujących narracji, nie tylko komunistycznej, ale również nacjocentrycznej czy patriarchalnej. Następujące przemiany nie miały charakteru rewolucyjnego, nie przystawały także do utrwalonej wizji przełomu i związanych z nim oczekiwań. W odczuwanym rozczarowaniu upatruję źródeł sceptycyzmu w ocenie roku 1989 w słowackim literaturoznawstwie, który może osłabnąć wraz z wypracowaniem nowych kategorii rozumienia i opisu procesu literackiego.

\section{Bibliografia}

Bakoš, Mikuláš, Problém vývinovej periodizácie slovenskej literatúry, Trnava 1944.

Barborík, Vladimír, Slovenská kritika pláva vo vodách Babylonu, w: Fórum mladej literárnej kritiky, red. A. Bžoch, M. Kasarda, Bratislava 1992.

Beasley-Murray, Tim, Súčasná slovenská literatúra, diabolská zmluva s teóriou a genitalisti, „Rak” 2000, nr 3.

Chrobáková, Stanislava, Literatúra v diskusii I, „Slovenská literatúra” 1999, nr 1.

Czapliński, Przemysław, Ślady przełomu. O polskiej prozie 1976-1996, Kraków 1997.

Drug, Štefan, Z literárnych sporov po novembri 1989, w: idem, Literatúra a politika po slovensky, Bratislava 2003.

Hochel, Igor, Vývinové kontexty a súvislosti, w: I. Hochel, L. Čúzy, Z. Kákošová, Slovenská literatúra po roku 1989, Bratislava 2007.

\footnotetext{
${ }^{39}$ P. Czapliński, op. cit., s. 166.
} 
Hvišč, Jozef, Marčok, Viliam, Bátorová, Mária, Petrík, Vladimír, Biele miesta v slovenskej literatúre, Bratislava 1991.

Jankowicz, Grzegorz, Marecki, Piotr, Palęcka, Alicja, Sowa, Jan, Warczok, Tomasz, Literatura polska po 1989 roku w świetle teorii Pierre'a Bourdieu. Raport z badań, Kraków 2014.

Jenčíková, Eva, Zajac, Peter, Situácia súčasnej slovenskej literatúry, „Slovenské pohl'ady” 1989, nr 2.

Kasarda, Martin, Literatúra si našla svoje miesto, stačí napísat' nekrológ, „Romboid” 2000, nr 6.

Kolektív autorov, Študentský prológ $k$ Nežnej revolúcii, Bratislava 2019.

Kornhauser, Julian, Międzyepoka. Szkice o poezji i krytyce, Kraków 1995.

Kršáková, Dana, Situácia súcasnej slovenskej literatúry 1, http://www.iliteratura.cz/Clanek/ 17307/situacia-sucasnej-slovenskej-literatury-1- (d.d. 15.03.2020).

Literatura polska po 1989 roku w świetle teorii Pierre'a Bourdieu. Podręcznik, red. G. Jankowicz, P. Marecki, M. Sowiński, Kraków 2015.

Majerek, Rafał, Przestrzenie pamięci - rewitalizacje mitu i próby reinterpretacji tradycji w dyskursie słowackim po 1989 roku, w: Kultury słowiańskie między postkomunizmem a postmodernizmem, red. M. Dąbrowska-Partyka, Kraków 2009.

Marčok, Viliam a kolektív, Dejiny slovenskej literatúry III. Cesty slovenskej literatúry druhou polovicou XX. storočia, Bratislava 2004.

Matejovič, Pavel, Literatúra, „život” a vy... (Anketa), „Rak” 1999, nr 6.

Matejovič, Pavel, Viac odvahy k premýšl'aniu, „Rak” 1996, nr 6.

Michalovič, Pavel, Malá úvaha o literatúre, o dobe a všeličom inom, „Romboid” 2000, nr 6.

Mikula, Valér, Estetikum či politikum? Medzníky v slovenskej literatúre po roku 1945, w: idem, Čakanie na dejiny. State k slovenskej literárnej histórii, Bratislava 2013.

Mikula, Valér, Hodnoty a literárne dejiny. K situácii slovenskej literárnej historiografie, w: idem, Čakanie na dejiny. State k slovenskej literárnej histórii, Bratislava 2013.

Mikula, Valér, Novodobá slovenská literatúra, w: idem, Čakanie na dejiny. State k slovenskej literárnej histórii, Bratislava 2013.

Nycz, Ryszard, Możliwa historia literatury, w: idem, Poetyka doświadczenia. Teoria nowoczesność - literatura, Warszawa 2012.

Rassloff, Ute, Poetika coolness? Mladá slovenská próza po roku 1989, „Rak” 1999, nr 5.

Součková, Marta, P[r]ózy po roku 1989, Bratislava 2009.

Součková, Marta, Różne formy podmiotu w literaturze słowackiej po 1989 roku, tłum. M. Buczek, w: Literatury stowiańskie po roku 1989. Nowe zjawiska, tendencje, perspektywy, t. 3: Podmiotowość, red. B. Czapik-Lityńska, Warszawa 2005.

Šrank, Jaroslav, Poème fatal (Text generation. Zvodcovia zmyslu), „Romboid” 2000, nr 6.

Šrank, Jaroslav, Situácia slovenskej literatúry na konci 20. a začiatku 21. storočia (K pluralizmu literárneho pol'a), w: Tradycja $i$ wyzwania. Metodologia badań slawistycznych XX i XXI wieku, red. H. Mieczkowska, E. Solak, P. Fałowski, N. Palich, Kraków 2015.

Šútovec, Milan, Literatúra v diskusii, w: idem, Zo šedej zóny, Bratislava 1999. 
Šútovec, Milan, Začiatok sedemdesiatych rokov ako literárnohistorický problém, „Slovenské pohl'ady" 1989 , nr 1.

Taranenková, Ivana, Premeny poetík? (Niekol'ko poznámok k reflexii slovenskej literatúry po roku 1989), „Slovenská literatúra” 2009, nr 6.

Zajac, Peter, Literatura stowacka na końcu XX wieku, tłum. A. S. Jagodziński, „Literatura na Świecie" 2007, nr 7-8.

RAFAŁ MAJEREK, adiunkt w Instytucie Filologii Słowiańskiej Uniwersytetu Jagiellońskiego w Krakowie, zajmuje się problematyką najnowszej prozy słowackiej oraz zagadnieniami tożsamości narodowej i kulturowej Słowaków w perspektywie historycznej i współczesnej. Autor monografii Pamięć - mit - tożsamość. Stowackie procesy autoidentyfikacyjne $w$ okresie odrodzenia narodowego (Kraków 2011) i licznych artykułów publikowanych w Polsce i na Słowacji, członek Komisji Kultury Słowian Polskiej Akademii Umiejętności. 